Marta Milewska

Oddziałowe Biuro Badań Historycznych Instytutu Pamięci Narodowej w Warszawie; Akademia Finansów i Biznesu Vistula w Warszawie

iD ORCID: 0000-0003-3283-4037
OBLICZA WOJNY

TOM 4 - MIASTO I WOJNA

ŁÓDŹ2021 • ISBN 978-83-8220-617-3• s. 155-174 https://doi.org/10.18778/8220-617-3.09

\title{
ŻYCIE CODZIENNE W WARSZAWIE W POCZATKOWEJ FAZIE I WOJNY ŚWIATOWEJ
}

Streszczenie. Po wybuchu I wojny światowej życie codzienne w Warszawie uległo zmianie. W pamięci warszawiaków wielka wojna zapisała się jako trudny czas, w którym doświadczali niepewności, strachu i głodu. Brak rzetelnych informacji doprowadził do wybuchu paniki w mieście i chaosu komunikacyjnego. Celem artykułu jest omówienie różnych aspektów życia codziennego w stolicy i trudności, które były następstwem trwającej wojny. Przedstawiono także niedogodności aprowizacyjne mieszkańców oraz problemy opieki medycznej. Część artykułu zawiera treści dotyczące organizacji samopomocy w Warszawie w początkach I wojny światowej. Na podstawie tych informacji udało się ustalić, że dzięki rozbudowanym strukturom Komitetu Obywatelskiego i działalności innych instytucji dobroczynnych pomoc docierała do najbardziej potrzebujących.

Słowa kluczowe: życie codzienne, I wojna światowa, aprowizacja, stolica, Warszawa, mieszkańcy Warszawy

Po wybuchu I wojny światowej w 1914 r. ludność Warszawy znalazła się w trudnym położeniu. Mieszkańcy stolicy bez względu na wiek, płeć i pochodzenie doświadczali ciągłej niepewności jutra, uczucia głodu, chorób, zniszczeń miasta ${ }^{1}$. W obliczu zachwiania podstaw egzystencji szybko wzrastała liczba nędzarzy i żebraków oraz ludzi biednych i głodnych. Celem artykułu jest więc zwrócenie uwagi na zmiany, jakie nastąpiły w życiu codziennym mieszkańców stolicy po wybuchu I wojny światowej. Jak warszawiacy reagowali na nową sytuację, jak sobie z nimi radzili? Jakie towarzyszyły im emocje i jakim problemom

${ }^{1}$ K. Sierakowska, Zniszczenia miast i ludności. Dramat ludności cywilnej, [w:] Spoteczeństwo Mazowsza wobec wydarzeń I wojny światowej, red. A. Koseski, J. SzCZepański, Pułtusk 2017, s. 17-32. 
musieli stawić czoła? Z uwagi na bogatą bazę źródłową - dzienniki, pamiętniki i wspomnienia - życie codzienne mieszkańców Warszawy po wybuchu I wojny światowej zostało przedstawione w oparciu o wybrane materiały źródłowe. Odzwierciedlają one specyfikę doświadczenia wojny z perspektywy mieszkańców stolicy. Wojenna egzystencja została więc scharakteryzowana w oparciu o następujące aspekty życia codziennego: negatywne emocje towarzyszące mieszkańcom stolicy po wybuchu I wojny światowej, dezinformację i chaos komunikacyjny, napływ migrantów do miasta, wzrost przestępczości, trudności aprowizacyjne, pogorszenie warunków bytowych, choroby epidemiczne i zwiększającą się liczbę osób potrzebujących pomocy materialnej. Odpowiedzią na wymienione wyżej trudności życia codziennego była szeroko zakrojona akcja samopomocy, wynikająca z zakorzenionej od dawna wśród warszawiaków idei dobroczynności.

Analizując to, co działo się w Warszawie po wybuchu I wojny światowej, można stwierdzić, że mieszkańcom towarzyszyła szeroko rozumiana panika. Wzbudzał ją nie tylko wybuch wojny, ale też mobilizacja, brak rzetelnej informacji, szerzące się plotki, przemarsze wojsk oraz trudności dnia codziennego. Symptomami paniki był chaotyczny, nasilony ruch pieszy i kołowy oraz hałas i krzyki na ulicach. Antoni Marylski wspominał tamte chwile w następujący sposób:

Przeludniona Warszawa, kipiąca dniem i nocą warem i wirem życia wojennego, mrowie wojska i mobilizowanych mas ludzkich, szalona jazda i ryk niezliczonej ilości samochodów i motocykli, pędzące przez miasto galopem konne sztafety, polowanie przez żołnierzy na ulicach stolicy na konie, ekwipaże i wozy, oblężone przez publiczność banki, zawieszające wypłaty, natłoczone dworce i pociągi, alarmujące wiadomości o popsuciu wodociągów, stacji elektrycznej i gazowni o zamiarze Moskali wysadzenia Warszawy w powietrze, do czego miał być przykrywką wybuch składu amunicji przy cytadeli, to wszystko dawało wrażenie niezwykłości i zarazem stwarzało atmosferę podniecenie zdenerwowania ${ }^{2}$.

Panika była efektem strachu i utraty poczucia bezpieczeństwa. Zdaniem Katarzyny Sierakowskiej

Panikę wzbudzał sam wybuch wojny, mobilizacja, wyjazdy urzędników, plotki

- przy braku w wielu miejscowościach gazet w pierwszych dniach wojny, trudności

2 A. Marylski, Niemcy przed Warszawa. Epizod z Wielkiej Wojny (rok 1914), Warszawa 1921, s. 5-6. 
dnia codziennego, pojawienie się uciekinierów (...) Znamionami paniki były (...) na ogół nieuporządkowany, a nawet chaotyczny, nasilony ruch pieszy i kołowy, hałas, $\mathrm{krzyki}^{3}$.

Brak rzetelnej informacji i szerzące się pogłoski o zbliżającym się froncie potęgowały lęk. Strach towarzyszył także Marii Lubomirskiej, o czym świadczy jej zapisek:

Wielu rzeczy niezapomnianych wojna uczy, w mózg wtłacza rzeczy zupełnie niewojenne. Lecz zbliżający się grzmot armatni wszystko zagłusza, jak potężny basowy instrument górujący przeraźliwie nad pieśnią fletni, skrzypiec i piszczałek. Tylko płoną w umyśle te wielkie wyrazy: „Bóg, Przemoc, Strach, Śmierć, Ojczyzna”.

Olbrzymi chaos panował na dworcach kolejowych. Doświadczali go zarówno ci, którzy próbowali wyjechać z Warszawy bądź wjechać do stolicy lub po prostu wrócić do swojego stałego miejsca zamieszkania. Wacław Jędrzejewicz po wybuchu wojny postanowił przerwać wakacje i przyjechać do swojego mieszkania w Warszawie. O trudnościach związanych z powrotem do domu pisał:

Żądano jakiś przepustek, dokumentów - musiałem je gdzieś wyrabiać i ostatecznie po dwóch czy trzech dniach udało się nam przybyć w przepełnionym pociągu do Warszawy. Po drodze, na stacjach, czuć już było atmosferę wojenną. Wszędzie mnóstwo żołnierzy i sprzętu wojskowego, pociągi pasażerskie, kursujące nieregularnie i dokuczliwa plaga pierwszego okresu wojny - brak drobnych5.

O trudnościach z powrotem do Warszawy pisała też Janina Gajewska. Podróż jej znajomych z Milanówka do stolicy trwała sześć godzin, podróżujących zaś z Grodziska do miasta osiem godzin. Sytuację tę podsumowała zdaniem: „Tak się przedstawiają teraz podróże”6. Tłok panował nie tylko na dworcach, ale też w pociągach, o czym pisał Cezary Jellenta w następujący sposób:

Wagony czyniły wrażenie, jak gdyby je zanurzono w jakimś gęstym, lepkim mrowisku ludzkim, a potem wyciągnięto na wierzch. Była to jakaś wielogłowa masa

${ }^{3}$ K. Siera Kowska, op. cit., s. 20.

${ }^{4}$ Pamiętnikksiężnej Marii Zdzistawowej Lubomirskiej 1914-1918, do druku przygotował J. PAJEwski, oprac. A. Kosicka-Pajewska, Poznań 2002, s. 176 (zapis z 11 V 1915).

5 W. JęDRZEJew ICZ, P.O.W. i Batalion Warszawski, Moja stużba 1914-1915, Warszawa 1939, s. 39 .

${ }^{6}$ Ta wojna zmieni wszystko... Dziennik Janiny Gajewskiej, oprac. A. WAJs, Warszawa 2014, s. 38 . 
żyjących stworzeń, oblepiająca z zewnątrz i wewnątrz wielkie pudła zielone i żółte ${ }^{7}$.

Poczucie niepewności sprawiło, że część mieszkańców próbowała wyjechać z Warszawy, ale byli też tacy, którzy chcieli dostać się do miasta, wierząc, że ten trudny czas łatwiej będzie przetrwać w dużym skupisku ludzi. Dworzec kolejowy stał się więc miejscem bardzo ruchliwym. Nie brakowało też dramatycznych scen związanych z odjazdem zmobilizowanych żołnierzy na wojnę, którym towarzyszył płacz. Rekrutacja i wysłanie na front mężczyzn, będących często głównymi żywicielami rodziny, dla wielu było wydarzeniem traumatycznym, mającym duży wpływ na dalsze funkcjonowanie rodziny - odtąd kobiety i nieletni synowie musieli sami zarobić na utrzymanie ${ }^{8}$.

Przeciągające się walki i ciągłe poczucie niepewności powodowały spadek odporności psychicznej mieszkańców Warszawy. Na skutek powtarzającego się ostrzału ginęła ludność cywilna stolicy. O tragizmie warszawiaków Maria Lubomirska pisała: „Dzień był męczący, prócz armat o tonie doniosłym furczące nad głową aeroplany niemieckie darzyły Warszawę bombami. Spadło ich około dziesięciu, raniąc mniej więcej pięćdziesiąt osób, a tych kilka śmiertelnie. Najgroźniejszy wybuch miał miejsce przy kolei wiedeńskiej"9. Widok zabitych i rannych był przerażający. Strach potęgowali także poszkodowani żołnierze, których przetransportowano z pola bitwy. Dźwięk nadciągających aeroplanów wzbudzał jednak ciekawość warszawiaków. Widok niemieckich samolotów nad stolicą Stefan Krzywoszewski relacjonował: „Niebawem nad Warszawą jęły krążyć «gołąbki» niemieckie, ich pociski wszakże nie wyrządzały większych szkód. Pewnego ranka ukazały się w chmurach potworna kiełbasa Zeppelina"10. Wyprawy na pobojowiska i zbieranie „wojennych” gadżetów służyło zaspokajaniu ludzkiej ciekawości oraz pozwalało oswoić się z wojną i jej skutkami ${ }^{11}$. O ciekawskich warszawiakach wspominał też Cezary Jellenta, pisząc: „Oglądali każda norę transzei, każdą dziurę w drzewie, każdą świeżą mogiłkę, szukali nabojów, ładowali do koszy łuski szrapneli, wchodzili do blindaży"12.

\footnotetext{
C. Jellenta, Wielki zmierzch, Warszawa 1985, s. 92 (zapis z 24 X 1914).

${ }^{8}$ K. Siera Kowska, op. cit., s. 20.

9 Pamiętnik księżnej Marii Zdzistawowej Lubomirskiej..., s. 68 (zapis z 16 X 1914).

10 S. Krzy woszewski, Dtugie życie, t. 1, Warszawa 1947, s. 256.

${ }^{11}$ K. Siera KOWSKa, op. cit., s. 25.

12 C. Jellenta, op. cit., s. 98-99 (zapis z 26 X 1914).
} 
Maria Lubomirska zwróciła uwagę:

Obecną rozrywką warszawiaków są wycieczki na pobliskie pola bitwy. Tłumy jadą do Pruszkowa, aby się przypatrzeć okopom i przywieść do domu jaką wojenną po Niemcach pamiątkę. Niektórzy przywożą z dumą niewystrzelone szrapnele, które wybuchają przy pierwszej nieostrożności, rażąc śmiertelnie dom cały ${ }^{13}$.

Wśród osób odwiedzających pobojowiska były także kobiety. „Telimeny warszawskie (...) - pisał Stefan Krzywoszewski - grzybów w lesie szukały na polach raszyńskich i pod Pyrami pikielhaub niemieckich"14, co pozwalało zaspokoić ciekawość oraz było też okazją do rabowania zwłok.

W obliczu konfliktu zbrojnego w społecznych organizacjach działających na terenie Królestwa Polskiego, a więc i w Warszawie, dojrzewała myśl utworzenia instytucji obywatelskich, które zajęłyby się organizacją akcji ratunkowej dla ludności cywilnej. Celem powstających organizacji było zapewnianie pomocy materialnej osobom znajdującym się w trudnej sytuacji życiowej ${ }^{15}$. Przedłużający się stan wojny i w związku z tym pogorszenie sytuacji materialnej mieszkańców spowodowały, że warszawskie instytucje dobroczynne, działające na rzecz cierpiących, nabierały coraz większego znaczenia. Pierwszą instytucją, która organizowała akcje dobroczynne w czasie wojny był Centralny Komitet Obywatelski16. W dniu 1 sierpnia 1914 r. w mieszkaniu Włodzimierza Czetwertyńskiego w Warszawie zebrało się około stu przedstawicieli różnych instytucji i towarzystw w celu powołania instytucji, która reprezentowałaby ludność stolicy ${ }^{17}$. W ciągu kilku dni powstał Komitet Obywatelski miasta stołecznego Warszawy, a następnie Centralny Komitet Obywatelski ${ }^{18}$.

Komitet zajmował się udzielaniem pomocy materialnej osobom poszkodowanym na skutek działań wojennych, pozostającym bez pracy i rodzinom rezerwistów powołanych do wojska. Do zadań Komitetu należała także organizacja

13 Pamiętnik księżnej Marii Zdzistawowej Lubomirskiej..., s. 73-74 (zapis z 24 X 1914).

14 S. KRZYwoszewsKi, op. cit., s. 257.

15 M. PrzeniosŁo, Organizacje samopomocy spotecznej w Królestwie Polskim w latach I wojny światowej, „Niepodległość i Pamięć” 2011, nr 1, s. 57.

${ }^{16}$ E. KoŁodZiej, Dziatalność samopomocowa podczas I wojny światowejna Mazowszu, [w:] Spoteczeństwo Mazowsza wobec wydarzeń..., s. 37.

${ }_{17}$ M. MilewsKa, Idea dobroczynności w Warszawie w czasie I wojny światowej na przyktadzie wybranych instytucji, [w:] Warszawskie oblicza niepodlegtości, red. E. Wajs-BARYŁA, Warszawa 2019, s. 24.

18 J. Szczepański, Powstanie Centralnego Komitetu Obywatelskiego Królestwa Polskiego w Warszawie we wrześniu 1914 roku wświetle sprawozdania Wtadystawa Grabskiego, „Teki Archiwalne. Seria Nowa" 2011, t. 11, s. 122. 
osób do budowy fortyfikacji, szpitali i ochronek w granicach miasta ${ }^{19}$. Na posiedzeniu Centralnego Komitetu Obywatelskiego w dniu 12 września 1914 r. powołano następujące sekcje: finansową, komitetów miejscowych, pośrednictwa handlowo-przemysłowego, szacunkową, sanitarną, robót publicznych i pośrednictwa pracy ${ }^{20}$. Warto zaznaczyć, że członkowie - założyciele dostrzegali w nim szansę na zalegalizowanie całego polskiego ruchu narodowego ${ }^{21}$.

Osobą, która odegrała istotną rolę w tworzeniu Centralnego Komitetu Obywatelskiego był Władysław Grabski - ówczesny wiceprezes Centralnego Towarzystwa Rolniczego. W skład Komitetu wchodziło dwunastu obywateli, przebywających na stałe na terenie Warszawy, którzy bez większych trudności mogli uczestniczyć w jego spotkaniach ${ }^{22}$. Komitet zajmował się: dostarczaniem węgla, drzewa, soli, nafty, mąki, drożdży i innych artykułów pierwszej potrzeby; zapewnieniem węgla i materiałów dla tych fabryk, których działalność miała szczególne znaczenie dla utrzymania właściwego funkcjonowania społeczeństwa; pomocą w znalezieniu zatrudnienia robotnikom (poprzez tworzenie biur pośrednictwa pracy); wsparciem materialnym osób pozostających bez pracy; organizowaniem robót publicznych i środków niezbędnych do ich wykonywania ${ }^{23}$. Po zajęciu stolicy przez Niemców, Centralny Komitet Obywatelski został rozwiązany, a na jego miejsce utworzono Radę Główną Opiekuńczą ${ }^{24}$. Likwidacja nie objęła jednak Komitetu Obywatelskiego Miasta Warszawy, który jako instytucja dobroczynna pomagał mieszkańcom stolicy w ich codziennym egzystowaniu w czasie wojny ${ }^{25}$.

Po wybuchu I wojny światowej w krajobraz Warszawy wpisany był też widok uchodźców, czyli mieszkańców mniejszych miejscowości i wsi, którzy zdecydowali się czasowo przenieść do stolicy z nadzieją, że w większej zbiorowości łatwiej będzie przetrwać czas wojny. Wobec napływu ludności z terenów objętych

19 J. Molenda, Polska w pierwszej wojnie światowej, Warszawa 1973, s. 127.

${ }^{20}$ Archiwum Akt Nowych w Warszawie (dalej: AAN), Centralny Komitet Obywatelski (dalej:

CKO), sygn. 3, Protokół z posiedzenia Centralnego Komitetu Obywatelskiego z 12 IX 1914 r.

${ }^{21}$ E. KoŁodZIEJ, op. cit., s. 37-41.

${ }^{22}$ ANN, CKO, sygn. 3, Protokół z posiedzenia Centralnego Komitetu Obywatelskiego z 11 IX $1914 \mathrm{r}$

23 J. SzCZepański, op. cit. s. 137-138; M. Milewska, op. cit., s. 24.

${ }^{24}$ E. Faszcza, Okoliczności powotania Rady Gtównej Opiekuńczej, „Białostockie Teki Historyczne" 2017, t. 15, s. 141.

25 W. Grabski, A. Ża вко-Potapowicz, Polska w czasie Wielkiej Wojny, t. 2: Historia spoteczna. Ratownictwo spoteczne w czasie wojny, Warszawa 1932, s. 115-117. 
działaniami wojennymi w sierpniu 1914 r. pojawiła się pilna potrzeba utworzenia schronisk.

Sytuacja straszna - pisał Stanisław Dzierzbicki w pamiętniku z okresu wojny - dziesiątki tysięcy ludzi wygnanych ze spalonych wsi i miast zalega drogi, tamując ruchy wojsk. Wczoraj gubernator warszawski otrzymał wiadomość, że około Jabłonny zebrało się około trzydziestu tysięcy uciekającej ludności, której nie chcą wpuścić do Warszawy, a która nie ma co jeść, ani gdzie podziać się ${ }^{26}$.

O pochodzie ludności wiejskiej przez Warszawę Maria Lubomirska pisała: „ulice są przepełnione wiejskimi furmankami wiozącymi bezdomnych, uciekających z mizernym dobytkiem przed luką lub pożogą. Do wozów przytroczone są cielęta, krowy, konie, na wozie spoczywają kuferki, pierzyny, dzieci. Ból i zamęt. Pochód beznadziejności”27. O przybywającej do Warszawy ludności wspominał Andrzej Wierzbicki:

największa gehenna czekała ludność wysiedloną przymusowo ze swoich siedzib i pędzoną wprost przed siebie, gdzie oczy poniosą. To były niekończące się karawany wozów naładowanych resztą ocalałego dobytku, ze starcami i dziećmi, uwiązanymi na postronkach krowami, żywicielami rodziny, i goniącymi resztką sił gromadami ludzi z tępą rozpaczą w oczach ${ }^{28}$.

Komitet Obywatelski miasta Warszawy w dniu 14 sierpnia 1914 r. podjął uchwałę w sprawie powołania Sekcji Bezdomnych i tworzenia schronisk, przeznaczonych dla osób, którym wojna zabrała dach nad głową ${ }^{29}$. Osoby przybywające ze wsi kierowane były więc do Doliny Szwajcarskiej, co potwierdziła Halina Rodzińska z Lilpopów, pisząc: „Budynek w Dolinie Szwajcarskiej stał się punktem zbornym dla bezdomnych, ofiar wojny, w wielkich salach balowych zorganizowano dożywianie i rozdawnictwo odzieży" ${ }^{30}$. W schroniskach pensjonariusze mieli także zapewnioną pomoc medyczną. Istniała jednak obawa, że brak podstawowych urządzeń sanitarnych i skupienie tak wielu osób w jednym miejscu może prowadzić do wybuchu epidemii.

26 S. Dzierzbicki, Pamiętnik z lat wojny 1915-1918, Warszawa 1983, s. 54 (zapis z 20 VIII 1914).

27 Pamiętnik księżnej Marii Zdzistawowej Lubomirskiej..., s. 64 (zapis z 11 X 1914).

28 A. Wierzbicki, Żywy Lewiatan. Wspomnienia, Warszawa 2001, s. 183 (zapis z 1915).

29 Kalendarzyk polityczno-historyczny miasta stotecznego Warszawy na rok 1917, Warszawa 1916, s. $105-106$.

30 H. Arturowa Rodzińska, Nasze wspólne życie, Warszawa 1980, s. 46. 
Gwałtowny napływ bezdomnych do Warszawy skłonił Komitet Obywatelski do energicznej akcji tworzenia schronisk. W pierwszym roku wojny na terenie Warszawy powstały pięćdziesiąt dwa schroniska, w których dach nad głową i ciepłą strawę znalazło ok. 60000 osób. We wspomnianym wyżej czasie Komitet Obywatelski Miasta Warszawy zorganizował osiemnaście hoteli - gospód dla inteligencji - oraz internat dla bezdomnych dzieci przy ul. Ceglanej 7. Stan zdrowia pensjonariuszy schronisk nie był dobry, dlatego równolegle utworzono szpitaliki, a właściwie punkty obserwacji lekarskiej i pięć szpitali wyposażonych w sto osiem łóżek ${ }^{31}$. „Po ewakuacji ludności czasowo przebywającej w Warszawie przeprowadzonej przez Niemców w stolicy pozostali tylko Ci, którzy ze względu na wiek lub kalectwo nie mogli być pozbawieni opieki”"32. W tej sytuacji Sekcja Bezdomnych zwróciła się do Wydziału Pomocy z prośbą o przekształcenie schronisk w przytułki dla starców, kalek i dzieci, czyli instytucje o charakterze opiekuńczo-wychowawczym ${ }^{33}$.

Mieszkańcy Warszawy przygotowywali się do wojny od momentu ogłoszenia mobilizacji. Przygotowania te polegały głównie na gromadzeniu zapasów żywności z obawy przed gwałtownym wzrostem ich cen. O robieniu zapasów pisała również Janina Gajewska: „Onegdaj zakupiliśmy z mamusią: cukru, kaszy, słoniny, grochu i makaronu dla Tatusia, bulionu u czekolady itp. Mamy też zapas kartofli, węgli, nafty, trzydzieści funtów mąki i parę żywych kurcząt, które się karmi odpadkami z obiadu" ${ }^{34}$. Kolejki przed sklepami na ulicach Warszawy wskazywały na to, że mieszkańcy poważnie traktowali wieści o zbliżającym się konflikcie zbrojnym. Według Marii Kurman wraz z pierwszym podejściem wojsk niemieckich pod Warszawę „We wszystkich sklepach spożywczych robiono tłumnie duże zakupy, brakło już chleba, soli, opału"35. W Warszawie z obawy przed wzrostem cen powołano tzw. Sekcję Żywnościową, która miała zajmować się dostarczaniem na warszawski rynek dostatecznej ilości produktów żywnościowych, by położyć kres spekulacyjnym zakusom hurtowników. Komitet Obywatelski dążył do tego, aby w Warszawie w czasie wojny działała

\footnotetext{
${ }^{31}$ Ibidem, s. 106-109.

32 M. MilewsKa, op. cit., s. 26.

${ }^{33}$ Kalendarzyk polityczno-historyczny..., s. 110-113.

${ }^{34}$ Ta wojna zmieni wszystko..., s. 29 (zapis z 2 VIII 1914).

35 M. Kurman, Z wojny 1914-1921. Przeżycia, wrażenia i refleksje mieszkańców Warszawy, Warszawa 1923 , s. 35.
} 
rozbudowana sieć sklepów komitetowych, by w ten sposób wpływać na regulację cen podstawowych artkułów żywnościowych ${ }^{36}$.

Po wybuchu I wojny w 1914 r. znaczna część mieszkańców Warszawy pozostała bez pracy i środków do życia. W pierwszym okresie trwania wojny w stolicy wyraźnie zmieniła się sytuacja materialna mieszkańców.

W mieście stołecznym podczas pierwszej wojennej jesieni i zimy brakowało przede wszystkim opału. No i gotówki - już w tym okresie, bowiem wiele osób straciło pracę. Dla ludności zwłaszcza robotniczej, która i przed wybuchem wojny żyła na granicy ubóstwa, brak wynagrodzenia bardzo szybko skutkował nędzą ${ }^{37}$.

Sytuacja żywnościowa w Warszawie wraz z upływem czasu stawała się więc coraz poważniejsza. O fakcie tym pisała też Halina Rodzińska:

Zamiast pszennych, chrupkich bułek kucharka przynosiła z targu - jak się jej powidło - ciemny kwaśny chleb z obierzyn kartoflanych, ciężki jak ołów i trudny do strawienia. Aromatyczną poranną kawę zastąpiła namiastka z polnego owsa lub wywar z suszonych skórek jabłecznych. Mycie też przestało być przyjemne, bo zamiast toaletowych mydeł Pulsa kupowaliśmy jakiś gliniasty produkt przemieszany z piaskiem ${ }^{38}$.

Trudności aprowizacyjne w Warszawie pojawiły się jesienią 1914 r., a wraz z upływem czasu, stopniowo nasilały się. Mieszkańcy miasta już w początkowej fazie I wojny światowej odczuwali głód oraz wzrost cen żywności.

Priorytetowym zadaniem Komitetu Obywatelskiego stało się więc bieżące prowiantowanie miasta i gromadzenie zapasów artykułów spożywczych pierwszej potrzeby. Dostarczenie produktów żywnościowych do Warszawy powierzono specjalnie w tym celu utworzonej przez Komitet Obywatelski Sekcji Żywnościowej. „Komitet Obywatelski dążył do tego, aby Warszawę, mimo tragizmu wojny, pokryła gęsta sieć sklepów komitetowych, by trzymać w ryzach detalistę i w ten sposób wpływać na regulację cen podstawowych artkułów żywnościowych" ${ }^{39}$. Sekcja Żywnościowa zajmowała się więc organizacją sklepów,

\footnotetext{
36 Kalendarzyk polityczno-historyczny..., s. 128-130.

37 K. SierakowsKa, op. cit., s. 28.

38 H. Arturowa RodzińsKa, op. cit., s. 44.

39 M. MilewsKA, op. cit., s 26-27.
} 
sprzedażą małego hurtu, dostarczaniem artykułów żywnościowych instytucjom dobroczynnym oraz prowiantowaniem Sekcji Rozdawniczej ${ }^{40}$.

Ze względów aprowizacyjnych teren miasta stołecznego Warszawy został podzielony na osiem dzielnic. W każdej z nich zakładano od trzech do sześciu sklepów. Na skutek tej akcji do końca 1914 r. na ternie Warszawy uruchomiono trzydzieści cztery sklepy komitetowe. Sekcja Żywnościowa przygotowywała i przekazywała Komisji Rozdawniczej paczki dla osób potrzebujących pomocy. W skład paczki dla trzyosobowej rodziny wchodziły następujące artykuły: jeden funt mąki, pół funta kaszy, pół soli, osiem łutów słoniny plus dwa funty chleba ${ }^{41}$. Od momentu wybuchu wojny przed warszawskimi piekarniami ustawiały się kolejki. Chleb stał się produktem deficytowym. W 1915 r. jednym z głównych zadań Sekcji Żywieniowej było dążenie do pozyskania większej ilości chleba dla Sekcji Rozdawnictwa, Tanich Kuchni i innych instytucji filantropijnych. Oszacowano, że w tym czasie Sekcja Żywnościowa dostarczała 10040 pudów chleba, czyli pół funta na osobę $e^{42}$. Drugim artykułem, którego wciąż brakowało, było mleko. W ramach Sekcji Żywnościowej powołano Komisję Mleczarską, która miała sprawować nadzór nad handlem mlekiem ${ }^{43}$. Ludność Warszawy w 1915 r. skarżyła się na brak jeszcze jednego podstawowego artykułu żywieniowego - ziemniaków. Fakt ten odnotowała także Maria Lubomirska w swoim pamiętniku:

Ostatnimi czasy kartofle z kolei przewożone są do miasta już tylko nocą, inaczej tłum rozgrabiał zawartość wozów ${ }^{44}$. Przeciwdziałanie spekulacji artykułami spożywczymi i odpowiednie zaprowiantowanie stolicy zostało tylko w części zrealizowane. Wpłynęły na to nie tylko zniszczenia wojenne, ale też trudności komunikacyjne i korupcja rosyjskich urzędników kolejowych ${ }^{45}$.

W obliczu pogarszających się warunków materialnych ogromne znaczenia miała pomoc organizowana przez Komitet Obywatelski, polegająca na rozdawnictwie podstawowych produktów żywieniowych. Potrzebujących wsparcia było tak wielu, że Komisja Rozdawnicza działająca przy Komitecie zdecydowała

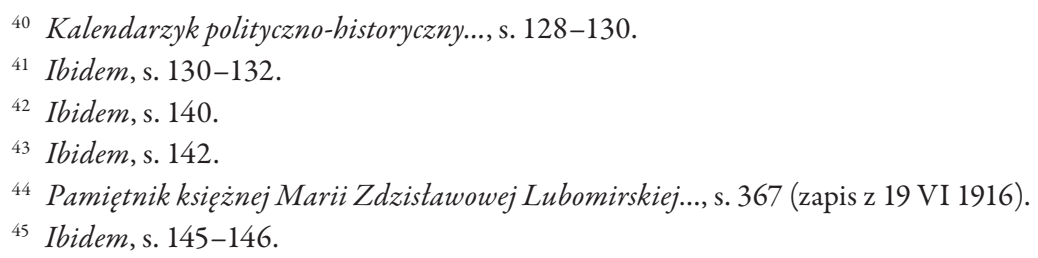


się na wprowadzenie bonów obiadowych do tzw. taniej kuchni. Komitet Obywatelski od początku wojny do końca 1915 r. uruchomił w Warszawie: trzydzieści siedem kuchni ludowych, sześć dla inteligencji, pięć typu mieszanego, trzynaście dla dzieci, trzy przy więzieniach, dwadzieścia herbaciarni ludowych, pięć herbaciarni dla inteligencji ${ }^{46}$. Rola taniej kuchni ograniczała się do przygotowania obiadów, a ich rozdysponowaniem zajmowała się Komisja Rozdawnicza. W świetle „Dziennika Komitetu Obywatelskiego Warszawy” z 1914 r. sklepy Komisji Rozdawniczej wydały 374000 porcji żywności oraz 359000 obiadów, 101000 bonów na chleb i parę tysięcy bonów na mleko i naftę ${ }^{47}$. W ciągu $1915 \mathrm{r}$. wydano w sumie 7015711 obiadów. Z każdym rokiem wojny wzrastało zapotrzebowanie na obiady w taniej kuchni. W 1916 r. w sumie w Warszawie działało sto kuchni i dwadzieścia jeden herbaciarni. Do dnia 1 lipca 1916 r. tania kuchnia wydała ogółem 30569186 porcji obiadowych ${ }^{48}$. W 1914 r. Janina Gajewska zanotowała: „przed sklepami komitetów i kuchniami, gdzie można było dostać gorącą strawę [wystają - dop. M.M.] całe gromady nędznie odzianych

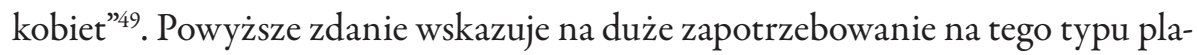
cówki dobroczynne.

Tanie kuchnie i rozdawnictwo żywności, mimo starań Komitetu Obywatelskiego, nie rozwiązały problemu aprowizacji. „Żywności wciąż brakowało, a skutki złego odżywiania nie dawały na siebie czekać. Na ulicach coraz częściej można było spotkać żebraków, czasem dotkniętych puchliną głodową" ${ }^{50}$. Trudności z zakupem podstawowych artykułów spożywczych sprzyjały negatywnym nastrojom wśród mieszkańców Warszawy. W stolicy z powodu deficytu żywności dochodziło nawet do zamieszek głodowych. Maria Dąbrowska wspominała, że: „Rozbijanie sklepów, rozruchy żywnościowe, wywołane to wszystko nie tylko przez głód, ale i przez Niemce, którzy aprowizację miasta chcą wziąć w swoje

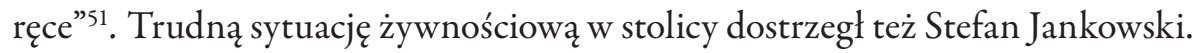
W pamiętniku zanotował: „Wielu ludzi przymiera głodem (choć tanie kuchnie wydają dziennie z górą 100000 obiadów) ukazuje się tyfus - jednym słowem

${ }^{46}$ Ibidem, s. 117-118.

47 „Dziennik Komitetu Obywatelskiego Miasta Warszawy” 1915, nr 1, s. 3-4.

${ }^{48}$ Kalendarzyk polityczno-historyczny..., s. 116-119.

49 J. Gajewska, Ta wojna zmieni wszystko..., s. 29 (zapis z 2 VIII 1914).

${ }^{50}$ K. Siera kowska, op. cit., s. 29.

${ }^{51}$ M. DąBrowska, Dzienniki 1914-1965, t. 1: 1914-1925, red. T. Drewnowski, Warszawa 2009, s. 82. 
głód i jego następstwa są już na widowni” ${ }^{2}$. O problemach związanych z aprowizacją pisano także na łamach prasy. W styczniu 1915 r. w „Gońcu Porannym” zamieszczono informację następującej treści: „Długotrwały kryzys ciągle zwiększa liczbę osób, dla której wydawanie żywności przez Komitet Obywatelski staje się jedyną ucieczką przed klęską głodu" "³ . Pogorszającą się sytuację aprowizacyjną odczuwała także warszawska inteligencja. Zdaniem Stefana Krzywoszewskiego „Obiad inteligenta warszawskiego składał się w tych czasach przeważnie z kartoflanki lub żuru. O śniadaniu i kolacji, o smaku chleba kartkowego, lepiej nie wspominać. Dochody utknęły, drożyzna szalała, najpotrzebniejszych produktów brakowało" ${ }^{54}$. Stanisław Dzierzbicki zaś w kwietniu 1916 r. pisał:

Sprawy żywnościowe w Warszawie zaostrzają się coraz bardziej, obecnie zaczyna brakować nawet kartofli. Rola sekcji Żywnościowej - wystawionej z jednej strony na niezadowolenie tłumów wygłodzonych, a z drugiej strony skrępowanej przez zarządzenia niemieckie i terroryzowanej przez ciągłe pogróżki jest nie do pozazdroszczenia ${ }^{55}$.

Problemy aprowizacyjne pojawiły się nie tylko Warszawie, był to problem wielu miast w Królestwie Polskim. Zdaniem Stanisława Dzierzbickiego stolica radziła sobie lepiej z zaopatrywaniem swoich mieszkańców w żywność niż inne miasta. W jego zapisach czytamy:

Dowóz produktów, utrudniony wskutek zupełnego prawie zatamowania ruchu kolejowego, jest jeszcze o tyle wystarczający, że poza czasowymi brakami opału, nafty soli itp. zaspokojenie koniecznych potrzeb życiowych jest możliwe, i głód, który Łodzi dał się już we znaki, nie sroży się jeszcze w Warszawie nawet wśród ludności biedniejszej i bezdomnych, a to głównie dzięki staraniom i pracy Komitetu Obywatelskiego ${ }^{56}$.

Problemy związane z dostawami żywności do stołecznego miasta Warszawy wynikały więc nie tylko ze zniszczeń wojennych, ale i z trudności komunikacyjnych. W wielu miejscach uszkodzeniu uległy drogi i linie kolejowe.

52 Pamiętniki Stefana Jankowskiego z lat 1914-1936, rkps, Ossol. 12011/III, mf. 2194, 7 III 1916, k. 674-675.

53 „Goniec Poranny” 1915, nr 3, s. 3.

54 S. Krzy woszewski, op. cit., s. 286.

55 S. Dzie RzBicki, op. cit., s. 125-126 (zapis z 6 VI 1916).

${ }^{56}$ Ibidem, s. 21 (zapis z 1 I 1915). 
Lepiej radzili sobie ci, którzy posiadali własne majątki ziemskie lub gospodarstwa poza miastem. Władze dopuszczały przywóz produktów z gospodarstwa do stolicy, ale tylko do własnego użytku i po uzyskaniu stosownego pozwolenia. „Stefan Jankowski wielokrotnie kursował do Warszawy, zaopatrując w żywność pozostałych w mieście rodziców" ${ }^{57}$. Podobnie postępował Stanisław Dzierzbicki - po uzyskaniu odpowiedniego pozwolenia udawał się na wieś po podstawowe artykuły żywnościowe. Zgoda władz nie oznaczała jednak, że wybrane produkty uda się przewieść do Warszawy, zwłaszcza kiedy wymagały one otrzymania dodatkowych pozwoleń. W pamiętniku Stanisława Dzierzbickiego czytamy:

W sobotę 15 bm. wyjechałem do Krzywonosi zajrzeć do gospodarstwa i przywieźć
różne produkty wiejskie, na które otrzymałem przepustkę. Pomimo, że miałem
pozwolenie na przywiezienie stu kilo mąki pszennej, nie mogłem dostać w żaden
sposób pozwolenia na zmielenie. (...) Obawiam się, żeby to samo nie spotkało mnie
z kartoflami, chociaż w ostatnich dniach wyszło rozporządzenie, że właścicielom
folwarków zamieszkałym w Warszawie ma być dozwolony przywóz niewielkich
ilości na swoją potrzebę

Migracje pomiędzy Warszawą a okolicznymi wsiami stały się czymś powszechnym, podobnie jak proceder przemytu żywności.

Sytuacja aprowizacyjna w Warszawie wyraźnie pogorszyła się po zajęciu stolicy przez Niemców. W tym czasie produktem deficytowym stał się chleb. $\mathrm{Na}$ ulicach Warszawy ustawiały się kolejki przed sklepami i piekarniami. O trudnościach związanych z zakupem chleba pisał też w swoim pamiętniku Stanisław Dzierzbicki: „Na razie więc w Warszawie jest zupełny brak mąki i chleb dochodzi do cen tak bajecznych, że ludność zaczyna wyczekiwać chwili zorganizowania sprzedaży mąki i chleba i zaprowadzenia kart chlebowych (Brotkarte), czego przedtem bardzo się obawiano" 59 . Słowa te, jak się okazało, miały proroczy charakter. Po uzyskaniu przez Komitet Obywatelski od władz niemieckich zgody na stworzenie instytucji, która zajmowałaby się podziałem chleba i mąki, powołano Komisję Rozdziału Mąki i Chleba dla stołecznego miasta Warszawy ${ }^{60}$. Komisja ta zdecydowała, że dzienna ilość

\footnotetext{
57 K. Siera kOWSKa, op. cit., s. 29.

58 S. DzIERzBICKI, op. cit., s. 258 (zapis z 19 IX 1917).

59 Ibidem, s. 69 (zapis z 5 X 1915).

60 M. Milewska, op. cit., s. 28.
} 
mąki na mieszkańca będzie wynosić 185 gramów ${ }^{61}$. Należy jednak zaznaczyć, że trudności aprowizacyjne w tym czasie odnotowano na terenie całego Królestwa Polskiego. Wartość wyżywienia w Kongresówce, jak podał Krzysztof Dunin-Wąsowicz, obniżyła się z 3000 kalorii w 1914 r. do około 900 kalorii na dobę wiosną $1918 \mathrm{r}^{62}$

Pierwsze kartki żywnościowe w Warszawie zaczęły funkcjonować we wrześniu 1915 r. ${ }^{63}$ „W systemie kartkowym stopniowo wprowadzano też dystrybucję innych produktów jak tłuszcze, ziemniaki czy kawa"64. Karta żywnościowa wydawana była na okres dwóch tygodni i zawierała dwadzieścia osiem kuponów, które pozwalały na zakup: jednej czwartej funta chleba (za każdy kupon) i pół funta mąki (za dwa kupony) ${ }^{65}$. Niepokój mieszkańców Warszawy spowodowany był dzienną ilością chleba. O problemie tym pisała też Maria Lubomirska w swoim dzienniku: „Doza chleba znów zmniejszona, na 115 gramów na osobę dziennie, czyli $1 / 4$ funta: to jest nic - to jest śmierć głodowa" ${ }^{36}$. Komitet Obywatelski, mimo swej aktywności i przedsiębiorczości, nie był w stanie zapewnić takiej ilości produktów, która widniała na wydawanych kartach aprowizacyjnych. Po miesiącu od wprowadzenia kart żywnościowych w październiku 1915 r. Stanisław Dzierzbicki pisał: „Organizacja kart chlebowych jak dotąd, zupełnie zawodzi. Sznury ludzi po kilka godzin wyczekują na chleb, którego ciągle bra-

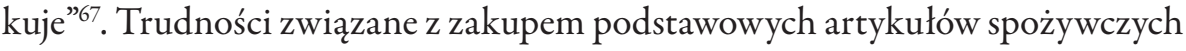
stały się też tematem listu Wacława Borowego, przebywającego w Warszawie, do jego żony. W liście tym w grudniu 1915 r. pisał:

przed piekarniami w godzinach przedpołudniowych - cierpliwe tłumy ludzi ustawione w sznurek nieprawdopodobnej wprost długości... - wszystkiego mało, to też do wszystkiego stosuje się system kartkowy: chleb za kartkami, węgiel i sól, za kartkami, będzie i cukier za kartkami. Czuje się pazury wojny ${ }^{68}$.

${ }^{61}$ Kalendarzyk polityczno-historyczny..., s. 146-148.

${ }^{62}$ K. Dunin-Wąsowicz, Warszawa 1914-1918, Warszawa 1989, s. 142.

${ }^{63}$ K. Siera Kowska, Śmierć - wygnanie - gtód w dokumentach osobistych. Ziemie polskie w latach Wielkiej Wojny 1914-1918, Warszawa 2015, s. 205.

${ }^{64}$ M. MilewsKa, op. cit., s. 28.

${ }^{65}$ Kalendarzyk polityczno-historyczny..., s. 148-150.

${ }^{66}$ Pamiętnik księżnej Marii Zdzistawowej Lubomirskiej..., s. 319 (zapis z 1 II 1916).

67 S. Dzierzbicki, op. cit., s. 90 (zapis z 4 XI 1915).

68 W. Borowy, Listy do żony, t. 1: 1914-1916, rkps, BN 7338, mf. (Warszawa 4 III 1915). 
Nie trzeba było długo na to czekać - od 15 grudnia 1915 r. wprowadzono karty na cukier. Norma dwutygodniowa na osobę: 275 gramów $^{69}$.

$\mathrm{Z}$ inicjatywy Komitetu Obywatelskiego w Warszawie powołano w sierpniu 1915 r. Wydział Pomocy dla Ludności ${ }^{70}$. W ramach tego wydziału utworzono następujące sekcje: pracy i pracy rękodzielniczej, komisji robót publicznych, kąpielową, pożyczkową, zapomóg, komisji pracy kobiet, mieszkaniową, bezdomnych, komisji do spraw urządzeń kwest ulicznych, bezdomnych Żydów, komisji rozdawniczej, zbierania ofiar, żywienia dzieci, pomocy dla inteligencji i biura wypłat zapomóg rodzinom rezerwistów ${ }^{71}$. Sekcje te odnosiły się do różnych dziedzin życia codziennego i wskazywały na skalę pomocy, jakiej potrzebowali mieszkańcy stolicy w czasie wojny. Bezpośrednią opiekę nad ludnością Warszawy do kwietnia 1916 r. sprawowała Sekcja Porządku i opieki domowej ${ }^{72}$. W Kalendarzyku polityczno-historycznym miasta stotecznego Warszawy poinformowano, że do zadań Rad Okręgowych należało: udzielanie opieki i pomocy ubogiej ludności i osobom, które w czasie wojny znalazły się w ciężkich warunkach bytowych, utraciły pracę lub nie miały możności utrzymania siebie i swojej rodziny ${ }^{73}$. Z uwagi na pogarszające się warunki bytowe, a tym samym wzrastającą liczbę potrzebujących pomocy, Warszawę podzielono na piętnaście okręgów. W każdym okręgu działali opiekunowie dzielnicowi, którzy utrzymywali bezpośredni kontakt z ludnością potrzebującą wsparcia. Opiekunowie dzielnicowi odgrywali istotną rolę w udzielaniu wsparcia potrzebującym. Docierali do osób potrzebujących w ich okręgach, pomagali w znalezieniu dachu nad głową i zatrudnienia oraz rozdawali bony żywieniowe, prowadzili wykaz osób korzystających ze wsparcia i sporządzali raporty ${ }^{74}$.

Trudności aprowizacyjne i pogorszenie warunków bytowych spowodowało w Warszawie wzrost zapotrzebowania na opiekę medyczną. Szybko dały o sobie znać choroby będące skutkiem niedożywienia - gruźlica, cholera, tyfus i czerwonka.

Aleksander dr Rosset pisał: „Główną troskę stanowiła walka z chorobami zakaźnymi, a przede wszystkim bardzo energiczna akcja w kierunku stłumienia

\footnotetext{
69 Kalendarzyk polityczno-historyczny..., s. 150.

70 Ibidem, s. 151.

${ }^{71}$ Ibidem, s. 151-152.

72 M. Milewska, op. cit., s. 30.

73 Kalendarzyk polityczno-historyczny..., s. 153.

${ }^{74}$ Ibidem, s. 61-66.
} 
cholery (której było 30 przypadków) oraz tyfusu plamistego i krwawej biegunki”75. Działania w zakresie ochrony zdrowia były jednak niewspółmierne do potrzeb, podobnie jak zaopatrywanie instytucji opieki medycznej w leki i pomoce medyczne. Liczba chorych w Warszawie wraz z przedłużającymi się działaniami wojennymi zwiększała się. Pogorszenie sytuacji zdrowotnej zauważyła też Maria Lubomirska, w której pamiętniku czytamy: „Ludzie umierają jak muchy; mam wrażenie, że wojna każdej słabości i chorobie przyspiesza kroku, pękają nadwątlone sprężyny, gną się ludzkie barki, nie wytrzymuje tętno ludzkich serc"76. Niepokój o zapewnienie opieki medycznej mieszkańcom Warszawy budziła również wzrastająca liczba rannych i chorych żołnierzy przybywających z frontu. Wielu spośród nich cierpiało na tyfus plamisty, gruźlicę, dezynterię i grypę hiszpankę, a więc choroby epidemiczne, które mogły się szybko rozprzestrzeniać na terenie miasta ${ }^{77}$.

W maju 1916 r. władze okupacyjne zezwoliły Radzie Głównej Opiekuńczej na prowadzenie w mieście opieki medyczno-sanitarnej ${ }^{78}$. Zadaniem nowo powstałej organizacji była działalność charytatywna, polegająca głównie na dostarczaniu żywności i na organizowaniu opieki medyczno-sanitarnej ${ }^{79}$. Rada Główna Opiekuńcza skupiała uwagę na opiece nad dziećmi oraz osobami bezdomnymi. Trudna sytuacja materialna dzieci w czasie I wojny światowej pozostawiała uszczerbek na ich zdrowiu. Negatywny wpływ wojny na stan zdrowia dzieci dostrzegali sami medycy. Jedna z lekarek Justyna Budzińska-Tylicka pisała:

Będąc od kilku lat lekarzem-higienistą szkół elementarnych, doskonale znam stan zdrowotny dzieci najuboższych sfer ludności Warszawy - i z przerażeniem widzę, jak te i tak w zwykłych normalnych czasach wątłe organizmy stają się dziś pastwą różnych chorób, a w pierwszym rzędzie gruźlicy ${ }^{80}$.

Z myślą o dzieciach Rada Główna Opiekuńcza zainicjowała w 1916 r. jedną z większych akcji pod hasłem „Ratujcie Dzieci”"1. W 1916 r. w akcję tę zaangażo-

75 Warszawa w pamiętnikach I wojny światowej, oprac. K. DunIn-WĄSOw ICZ, Warszawa 1971, s. $108-109$.

${ }_{76}$ Pamiętnik księżnej Marii Zdzistawowej Lubomirskiej..., s. 327 (zapis z 25 II 1916).

77 M. MilewsKa, op. cit., s. 30.

78 E. Faszcza, op. cit., s. 153.

${ }^{79}$ M. Milewska, op. cit., s. 31.

${ }^{80}$ Cyt. za. K. Siera Kowska, Zniszczenia miast i wsi..., s. 30.

${ }^{81}$ M. PrzeniosŁo, Rada Gtówna Opiekuńcza w latach 1915-1918. Wtadze, struktura wewnętrzna, formy dziatalności, [w:] Dzieje biurokracji, t. 4, cz. 2, Lublin 2011, s. 69. 
wanych było 1292 prelegentów i 16590 kwestarzy ${ }^{82}$. Rada Główna Opiekuńcza prowadziła też instytucje dobroczynne, wśród których liczbowo dominowały ochrony i przychodnie dla dzieci, szpitale dziecięce oraz jadłodajnie, herbaciarnie i schroniska dla dorosłych. Należy jednak zaznaczyć, że działalność samopomocowa w Warszawie w czasie wojny była też prowadzona przez inne stowarzyszenia społeczne oraz osoby prywatne ${ }^{83}$. Największy wkład w niesienie pomocy potrzebującym wsparcia mieszkańcom stolicy miało Warszawskie Towarzystwo Dobroczynności ${ }^{84}$. Pomocy warszawiakom w czasie wojny udzielały też: Towarzystwo Niesienia Pomocy Ofiarom Wojny, Polski Komitet Pomocy Sanitarnej i Centralne Towarzystwo Rolnicze, które poprzez swoje towarzystwa regionalne na wsiach zbierało środki finansowe dla biednych mieszkańców miast, w tym także Warszawy, pod hasłem „Wieś dla miast”85. Powyższe organizacje i stowarzyszenia prowadziły w stolicy własną działalność, niezależną od Komitetu Obywatelskiego, choć w wielu kwestiach z nim współpracowały ${ }^{86}$.

Lata I wojny światowej zapisały się w pamięci większości mieszkańców Warszawy jako trudny czas. Życie codzienne warszawiaków uległo zmianie z powodu braku rzetelnej informacji, paniki, strachu, trudności z aprowizacją, szerzących się chorób. Ocena wojny przez mieszkańców Warszawy związana była jednak z ich statusem społecznym i materialnym. Osoby wykształcone i lepiej sytuowane upatrywały w wojnie szans na odzyskanie niepodległości - gotowe ponosić różne ofiary. Dla biedniejszych mieszkańców stolicy wojna stanowiła zagrożenie egzystencji, dlatego wszelkimi siłami dążyli do zapewnienia przetrwania sobie i bliskim. Wzrost cen żywności powodował, że w Warszawie pojawili się też tacy, którzy wzbogacili się dzięki wojnie. Słusznie więc Zofia Nałkowska uznała, że:

wojna jest nie tylko rozlewem krwi, zdziczeniem i klęską. Jest jeszcze szerokim wirem dla oddechu, zdemaskowaniem nieznajomych wartości, grą higieniczną przerażających zdumień i niespodzianek. Ogląda się wtedy rozległe, przyrodnicze instynkty olbrzymich gromad ludzkich ${ }^{87}$.

82 AAN, Rada Główna Opiekuńcza, sygn. 612, k. 66-69.

${ }^{83}$ M. PrzeniosŁo, Rada Gtówna Opiekuńcza..., s. 70.

${ }^{84}$ D. Grinberg, E. Mazur, G. Pawlak, M. Sadowski, Res Sacra Miser. Dzieje Warszawskiego Towarzystwa Dobroczynności, Warszawa 2015.

${ }^{85}$ M. Przeniosıo, Rada Gtówna Opiekuńcza..., s. 607-610, s. 71.

${ }^{86}$ Ibidem, s. 70.

87 Z. Na€kowska, Dzienniki, t. 2: 1909-1917, Warszawa 1976, s. 342 (Górki 17 VIII 1914). 


\section{BIBLIOGRAFIA}

\section{Źródła archiwalne}

\section{Archiwum Akt Nowych w Warszawie}

Centralny Komitet Obywatelski, sygn. 3.

Rada Główna Opiekuńcza, sygn. 612.

\section{Biblioteka Narodowa w Warszawie}

Borowy W., Listy do żony, t. 1: 1914-1916, rkps, BN 7338, mf., Warszawa 4 III $1915 \mathrm{r}$.

Pamiętniki Stefana Jankowskiego z lat 1914-1936, rkps, Ossol. 12011/III, mf. 2194.

\section{Źródła drukowane}

Dąbrowska M., Dzienniki 1914-1965, t. 1: 1914-1925, red. T. Drewnowski, Warszawa 2009.

Dzierzbicki S., Pamiętnik z lat wojny 1915-1918, Warszawa 1983.

Jellenta C., Wielki zmierzch, Warszawa 1985.

Jędrzejewicz W., P.O.W. i Batalion Warszawski, Moja stużba 1914-1915, Warszawa 1939.

Kalendarzyk polityczno-historyczny miasta stotecznego Warszawy na rok 1917, Warszawa 1916.

Krzywoszewski S., Dtugie życie, t. 1, Warszawa 1947.

Marylski A., Niemcy przed Warszawa. Epizod z Wielkiej Wojny (rok 1914), Warszawa 1921.

Nałkowska Z., Dzienniki, t. 2: 1909-1917, Warszawa 1976.

Pamiętnik księżnej Marii Zdzistawowej Lubomirskiej 1914-1918, do druku przygotował J. Pajewski, oprac. A. Kosicka-Pajewska, Poznań 2002.

Rodzińska Arturowa H., Nasze wspólne życie, Warszawa 1980.

Ta wojna zmieni wszystko... Dziennik Janiny Gajewskiej, oprac. A. Wajs, Warszawa 2014.

Wierzbicki A., Żywy Lewiatan. Wspomnienia, Warszawa 2001. 


\section{Prasa}

„Goniec Poranny” 1915.

„Dziennik Komitetu Obywatelskiego Miasta Warszawy” 1915.

\section{Opracowania}

Dunin-Wąsowicz K., Warszawa 1914-1918, Warszawa 1989.

Faszcza Ł., Okoliczności powotania Rady Gtównej Opiekuńczej, „Białostockie Teki Historyczne" 2017, t. 15, s. 141-158.

Grabski W., Żabko-Potapowicz A., Polska w czasie Wielkiej Wojny, t. 2: Historia spoteczna. Ratownictwo spoteczne w czasie wojny, Warszawa 1932.

Grinberg D., Mazur E., Pawlak G., Sadowski M., Res Sacra Miser. Dzieje Warszawskiego Towarzystwa Dobroczynności, Warszawa 2015.

Kołodziej E., Dziatalność samopomocowa podczas I wojny światowej na Mazowszu, [w:] Spoteczeństwo Mazowsza wobec wydarzeń I wojny światowej, red. A. Koseski, J. Szczepański, Pułtusk 2017, s. 33-49.

Milewska M., Idea dobroczynności w Warszawie w czasie I wojny światowej na przyktadzie wybranych instytucji, [w:] Warszawskie oblicza niepodlegtości, red. E. Wajs-Baryła, Warszawa 2019, s. 23-34.

Molenda J., Polska w pierwszej wojnie światowej, Warszawa 1973.

Przeniosło M., Organizacje samopomocy spotecznej w Królestwie Polskim w latach I wojny światowej, „Niepodległość i Pamięć” 2011, nr 1, s. 57-72.

Przeniosło M., Rada Gtówna Opiekuńcza w latach 1915-1918. Wtadze, struktura wewnętrzna, formy dziatalności, [w:] Dzieje biurokracji, t. 4, cz. 2, Lublin 2011, s. 607-622.

Sierakowska K., Śmierć - wygnanie - gtód w dokumentach osobistych. Ziemie polskie w latach Wielkiej Wojny 1914-1918, Warszawa 2015.

Sierakowska K., Zniszczenia miast i ludności. Dramat ludności cywilnej, [w:] Spoteczeństwo Mazowsza wobec wydarzeń I wojny światowej, red. A. Koseski, J. Szczepański, Pułtusk 2017, s. 17-32.

Szczepański J., Powstanie Centralnego Komitetu Obywatelskiego Królestwa Polskiego w Warszawie we wrześniu 1914 roku w świetle sprawozdania Wtadystawa Grabskiego, „Teki Archiwalne. Seria Nowa" 2011, t. 11, s. 119-140.

Warszawa w pamiętnikach I wojny światowej, oprac. K. Dunin-Wąsowicz, Warszawa 1971. 


\section{Marta Milewska}

\section{EVERYDAY LIFE IN WARSAW IN THE BEGINNING PHASE OF THE FIRST WORLD WAR}

Summary. After the outbreak of World War I, everyday life in Warsaw changed. The great war was remembered by the inhabitants of Warsaw as difficult years, in which they experienced a sense of uncertainty, fear and hunger. The lack of reliable information led to panic in the city and communication chaos. The aim of the article is to show various aspects of everyday life in the capital and the difficulties that resulted from the ongoing war. The article also presents the supply difficulties of the inhabitants of the capital and the problems of medical care. Part of the article contains content about the organization of self-help in Warsaw at the beginning of the First World War. Based on this information, it was possible to establish that thanks to the extensive structures of the Citizens' Committee and the activities of other charity institutions, help reached the most impoverished ones.

Keywords: Everyday life, World War I, food supply, capital city, Warsaw, inhabitants 